\title{
Efficiency of Immediate Payment Systems as a Determinant of Safety
}

\author{
Agnieszka Parkitna*, Rafat Dolniak ${ }^{* *}$, Anna Czarnecka ${ }^{* * * *}$
}

\begin{abstract}
People who are looking for convenience and time savings are increasingly willing to reach for new technologies and methods designed to enhance the efficiency of their operations. After studying the literature on the Polish payment systems, the authors saw such convenience opportunities in the immediate payment systems that have been developing over the past several years. In this paper, the authors discuss the concept of payment system efficiency management and perform an assessment of efficiency of immediate payment system management by analyzing and comparing the Express Elixir and the BlueCash systems. The main goal of this paper is to evaluate the efficiency of management of immediate payment systems of the financial market operators providing such services on the Polish market. The problems presented in this work are of a theoretical nature and were preceded by literature analysis.
\end{abstract}

Keywords: payment system, financial services, efficiency, security.

Submitted: 10.11.2016 | Accepted: 21.02.2017

\section{Efektywność systemów płatności natychmiastowych jako wyznacznik bezpieczeństwa}

Człowiek przyzwyczajony do wygody i oszczędności czasu coraz chętniej sięga po nowe technologie i metody stużace zwiększeniu efektywności jego dziatania. Po przestudiowaniu literatury charakteryzujacej polski system płatności autorzy dostrzegli takie możliwości, jakie daje rozwijajacy się od kilku lat system ptatności natychmiastowej. W artykule omówiono pojęcia efektywności zarzadzania systemami płatniczymi oraz dokonano oceny efektywności zarządzania systemami ptatności natychmiastowej na podstawie prowadzonej analizy Systemu Express Eliksir i Systemu BlueCash. Gtównym celem prowadzonych badań byta ocena efektywności zarządzania systemami ptatności natychmiastowych podmiotów rynku finansowego świadczacych ustugi na rynku polskim. Zaprezentowane problemy majace charakter teoretyczny poprzedzone zostaty kwerenda literatury.

Słowa kluczowe: system płatności, usługi finansowe, efektywność, bezpieczeństwo.

Nadesłany: 10.11.2016 | Zaakceptowany do druku: 21.02.2017

JEL: E42, G21

Agnieszka Parkitna, PhD, Eng - Department of Management Infrastructure.

** Rafat Dolniak, MSc - Department of Management Infrastructure.

*** Anna Czarnecka, MSc, PhD student - Department of Management Systems.

Mailing address: Faculty of Computer Science and Management; Wrocław University of Science and Technology; ul. Wybrzeże Wyspiańskiego 27; 50-370 Wrocław; e-mail: agnieszka.parkitna@pwr.edu. pl; rafal.dolniak@gmail.com; anna.kilyk@pwr.edu.pl. 


\section{Introduction}

Effective management is a concept without a clear definition. For example, the definition presented by Grundy says that "Effective management of organizations calls for effective management of its projects" (Grundy, 2000). Another concept of this term is introduced by Artto and Dietrich: "This includes projects external to the organization, in which case they are mostly revenue generating projects, and internal with the purpose of improving, structuring and involving processes which lead to better internal efficiency, external effectiveness and success" (Artto and Dietrich, 2007). In economics, effective management can be connected with the definition of Pareto efficiency, which says that it is possible to achieve a distribution of goods that will maximize the usability status of all market participants. It means that Pareto efficiency is achieved when there is no possibility to improve the state of one individual without acting to the detriment of another individual. That is why efficiency requires appropriate allocation among customers so that their satisfaction is maximized (Samuelson and Nordhaus, 2012). During literature studies, it is easy to find proposed methods of evaluating effectiveness measurement which are based on ratio analysis (Wilczyński, 2014). In the case of a payment system, effective management of quality management indicators should be sought in the ways they themselves are measured. Unlike in traditional measuring methods, major factors for immediate payments are: the number of system users as well as the number, value and speed of settled transactions.

The validity of the discussed issues is justified by a low level of knowledge about the immediate payment system amongst its users. Also, the topic under discussion is important in view of the fact that Poland has one of the most modern systems in the world and sets the development pace in this area.

Polish literature does not provide abundant information about immediate payment systems. Most of such information takes the form of a brief mention which only points to the existence of such a system. It is worthy of note that the term "immediate payment system" is still relatively young and spreading surprisingly fast. It is estimated that in the near future these systems will become the main method of transferring money. Most of the information about these systems comes from Internet sources, especially from reports issued by the National Bank of Poland.

Security of payment systems is considered to be one of the main factors when analyzing their development. Unsatisfactory or insufficient security level for electronic transactions leads to the emergence of risky situations for all transaction participants. One of the ways to prevent the occurrence of such situations is to apply solutions that are used to guarantee security in traditional banking to e-banking. The system can be called "safe" when it enjoys both considerable trust and popularity among the users (Korzeń, 2006). That is why the main goal of this paper is to evaluate the effectiveness of immediate payment system management for Polish financial market operators as a determinant of safety and to assess the effect of minimizing the risk of their actions (Gowrisankaran and Stavins, 2004).

Research presented in this paper is the result of cooperation between Wroclaw University of Science and Technology and the Modern Business Management program implemented under the patronage of the Polish Bank Association.

\section{Types of Interbank Payment Systems}

There are two types of systems that support immediate payments in Poland. The first one is a clearing system, and the second one is a settlement system. Despite different meanings, these two concepts are very often confused. Clearing is a process of transmission, reconciliation and, in some cases, also a payment order confirmation (before the settlement process starts). It can also include liability compensation and determination of settlement position of system participants (Table 1).

Settlement, as the second concept, is an act which exempts from the obligations associated with cash transfers, financial instruments or securities, existing between settlement system participants (Table 2). 
Table 1. Evolution of the payment clearing service in Poland

\begin{tabular}{|l|c|c|c|c|c|}
\hline System name & Sybir & Elixir & Euro Elixir & $\begin{array}{c}\text { SEPA Euro } \\
\text { Elixir }\end{array}$ & $\begin{array}{c}\text { Express } \\
\text { Elixir }\end{array}$ \\
\hline Launch year & $1993-2004$ & 1994 & 2005 & 2008 & 2012 \\
\hline $\begin{array}{l}\text { Settlement } \\
\text { type }\end{array}$ & Net & Net & Net & Net & Gross \\
\hline Currency & Polish zloty & Polish zloty & Euro & Euro & Polish zloty \\
\hline Data carrier & $\begin{array}{c}\text { Paper } \\
\text { documents, } \\
\text { floppy }\end{array}$ & $\begin{array}{c}\text { Electronic } \\
\text { documents }\end{array}$ & $\begin{array}{c}\text { Electronic } \\
\text { documents } \\
\text { (MT103+SWIFT) }\end{array}$ & $\begin{array}{c}\text { Electronic } \\
\text { documents } \\
\text { (SEPA XML) }\end{array}$ & $\begin{array}{c}\text { Electronic } \\
\text { documents } \\
\text { (XML) }\end{array}$ \\
\hline $\begin{array}{l}\text { System owner } \\
\text { and operator }\end{array}$ & KIR & KIR & KIR & KIR & KIR \\
\hline $\begin{array}{l}\text { Transaction } \\
\text { speed }\end{array}$ & 3 days & $\begin{array}{c}\text { About 3 hours } \\
\text { (2-3 sessions) }\end{array}$ & $\begin{array}{c}\text { About 3 hours } \\
(2-3 \text { sessions })\end{array}$ & $\begin{array}{c}\text { About 3 hours } \\
\text { (2-3 sessions) }\end{array}$ & $\begin{array}{c}\text { A bout } \\
15 \text { seconds }\end{array}$ \\
\hline Payment type & Retail & Retail & Retail & Retail & Retail \\
\hline
\end{tabular}

Source: own work based on materials provided by the Automated Clearing House KIR.

Table 2. Evolution of the payment settlement service in Poland

\begin{tabular}{|l|c|c|c|c|}
\hline \multicolumn{1}{|c|}{ System name } & Sorb & Sorbnet & Sorbnet Euro & Sorbnet2 \\
\hline Launch year & 1993 & 1996 & $2002-2011$ & 2013 \\
\hline Settlement type & Gross & Gross & Gross & Gross \\
\hline Currency & Polish zloty & Polish zloty & Euro & Polish zloty \\
\hline Data carrier & $\begin{array}{c}\text { Paper } \\
\text { documents, } \\
\text { floppy }\end{array}$ & $\begin{array}{c}\text { Electronic } \\
\text { documents }\end{array}$ & $\begin{array}{c}\text { Electronic } \\
\text { documents }\end{array}$ & $\begin{array}{c}\text { Electronic } \\
\text { documents (SWIFT) }\end{array}$ \\
\hline $\begin{array}{l}\text { System owner } \\
\text { and operator }\end{array}$ & NBP & NBP & NBP & NBP \\
\hline Transaction speed & Several minutes & A few minutes & A few minutes & A few minutes \\
\hline Payment type & Large-value* & Large-value* & Large-value* & Large-value* \\
\hline
\end{tabular}

* some banks allow selected retail customers in this system.

Source: own work based on materials provided by the Automated Clearing House KIR.

One of two types of interbank payments can be used in the Polish financial services market:

- payments settled in the session mode (Elixir and Euro Elixir systems),

- payments settled in the near-real-time mode (SORBNET2, Express Elixir and BlueCash systems).

The immediate payment systems are rapidly gaining popularity around the world (Figure 1), which can be due to the users' desire for faster access to remittances during the transfers. The development of new technologies is forcing financial market institutions to adapt to new discoveries in order to take advantage of them (Kauffman and Wang, 2002).

\section{Characteristics of Immediate Payment Systems}

Immediate payment systems have many advantages such as a quick cash flow between the sender and recipients (in only a few seconds). This does not change the fact that this system has also many disadvantages. The best way to analyze advantages and disadvantages of this system is to do a SWOT analysis (Krawiec, 2011). 


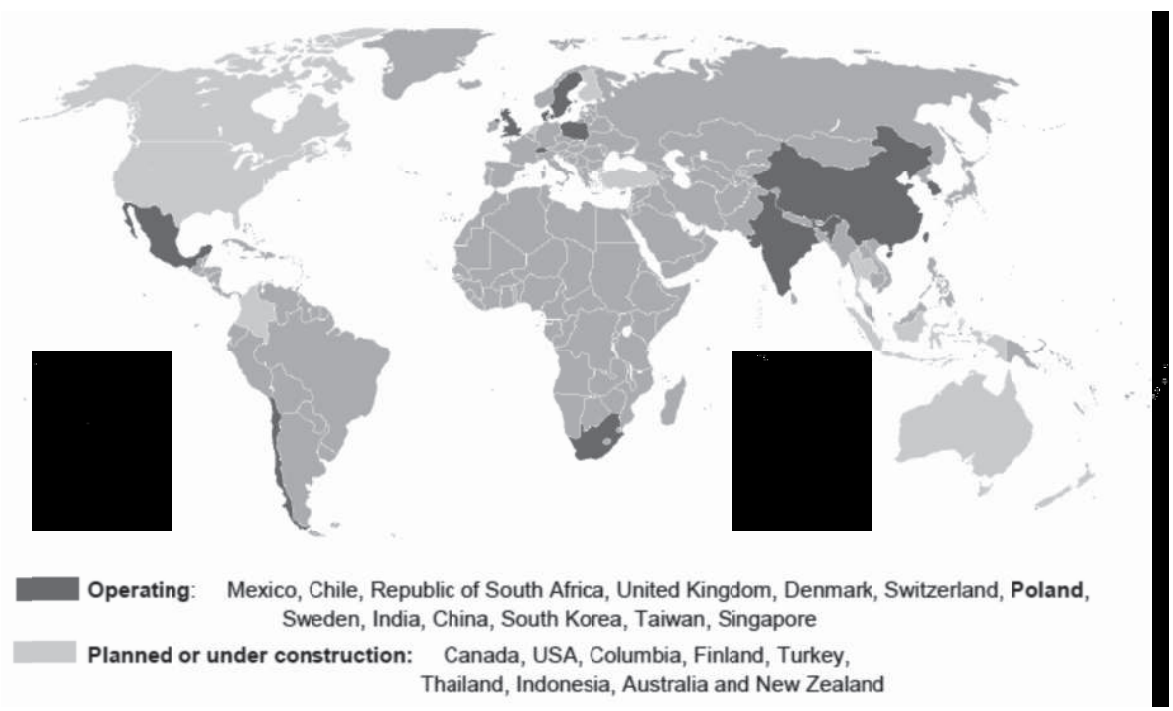

Source: Instant Payments Systems - analysis of selected systems, role of the central bank and development directions, National Bank of Poland, June 2015.

Table 3. SWOT analysis for immediate payment systems

\begin{tabular}{|c|c|}
\hline Strengths & Weaknesses \\
\hline $\begin{array}{l}\text { - Increase of revenues, } \\
\text { - Following global trends, } \\
\text { - Increase of competitiveness, } \\
\text { - Development of the organization, } \\
\text { - High-tech image. }\end{array}$ & $\begin{array}{l}\text { - High cost of system implementation, } \\
\text { - Costly maintenance of the system, } \\
\text { - Costly modernization of IT infrastructure. }\end{array}$ \\
\hline Opportunities & Threats \\
\hline $\begin{array}{l}\text { - Standardization of immediate payment } \\
\text { settlement standard, } \\
\text { - Takeover of payments settled in other } \\
\text { systems, } \\
\text { - Immediate payment systems become } \\
\text { the only used system (people expect faster } \\
\text { and more available cash transfers), } \\
\text { - Spread of mobile P2P payments, } \\
\text { - Opening up for the e-commerce market. }\end{array}$ & $\begin{array}{l}\text { - Lack of a uniform payment settlement } \\
\text { standards, which may lead to a financial } \\
\text { market split, } \\
\text { - Increased competition by creating other } \\
\text { immediate payment systems, } \\
\text { - Lack of cooperation leading to operational } \\
\text { connection at the national and international } \\
\text { levels, } \\
\text { - Low interest in other real time payment } \\
\text { types, like P2P mobile payments. }\end{array}$ \\
\hline
\end{tabular}

Source: own work.

Worthy of mentioning are also the risks associated with participation in an immediate payment system and the ways of minimizing them, connected with effective system management. According to Blue Media S.A., the primary source of risk linked to immediate payment systems lies in a possible increase in the so-called fraudulent transactions. To reduce this type of risk, Blue Media (in consultation with the Association of Polish Banks) has developed anti-fraud protection. 


\section{Effectiveness of Payment System Management}

Immediate payment system management is based mainly on information exchange, including free flow of information through effective distribution channels. The definition of distribution depends on the adopted research perspective. In simplified terms, a distribution channel can be defined as a set of following cells (individuals and institutions) crossed by streams of property (movement of products and payments for them) and information (related to communication between entities connected with the distribution channels) (Krzywda and Dolniak, 2014). In this case, the main elements to improve the efficiency of these systems will be information itself and the time needed to transfer it.

It is worth noticing that the effectiveness of system management is related to and plays a primary role in: profitability, productivity, efficiency, effectiveness and even in rationality (Skrzypek, 2012). Different approaches to effectiveness can be found in literature, namely the teleological and systematic approaches. The teleological approach treats efficiency as a factor in achieving the intended objective, and the systematic approach shows the relation between effect and effort. There also exists a combination of these two approaches, which defines effective system operation as a balanced use of available resources to accomplish a specific purpose (Wilczyński, 2014).

During the analysis of the immediate payment system, it is important not to rely on predefined indicators used in the literature only. Due to the nature of the activities, they will not be as reliable as the indicators developed by organizations administering immediate payment systems. Parameters which can be used by these indicators are: the number of system users, the number and value of settled transactions, the speed of settlement. Among these parameters, the number of entities is particularly important for future system development, because it provides a wider range, an increase of the amount of sent information (messages), as well as their value (Van Hove, 1999).

In the Polish immediate payment system, the main role is played by the BlueCash system, which offers access to immediate payments for 76 participants (compared to Express Elixir with only nine banks, data for the fourth quarter of 2015) - Table 4.

Table 4. Number of participants in Express Elixir and BlueCash

\begin{tabular}{|c|c|c|}
\hline & Express Elixir & BlueCash \\
\hline Q1 2013 & 6 & - \\
\hline Q2 2013 & 7 & 4 \\
\hline Q3 2013 & 8 & 9 \\
\hline Q4 2013 & 8 & 16 \\
\hline Q1 2014 & 8 & 24 \\
\hline Q2 2014 & 8 & 32 \\
\hline Q3 2014 & 8 & 42 \\
\hline Q4 2014 & 9 & 53 \\
\hline Q1 2015 & 9 & 57 \\
\hline Q2 2015 & 10 & 65 \\
\hline Q3 2015 & 9 & 72 \\
\hline Q4 2015 & 9 & 76 \\
\hline
\end{tabular}

Source: own work based on materials provided by the Automated Clearing House KIR and Blue Media S.A.

One of the advantages of the immediate payment system, often unused by banks, is the fact that they function 24 hours a day, 7 days a week, 365 days a year. The time during which it is possible to use the system is one of the key factors of its effectiveness. Unfortunately, banks use this system only for a limited time, which reduces the pace of its rapid growth. In the Express Elixir system, only five banks offer constant access to immediate payments (24/7/365), and the rest provide access only at fixed hours (for example three banks - including mBank for corporate clients - offer such access on Saturdays and Sundays). In case of the BlueCash system, eleven banks operate in the 24/7/365 mode, three banks offer access on Saturdays and Sundays, and only three on Sundays.

In order to measure the effectiveness of immediate payment system management, the operators of Express Elixir and BlueCash meticulously gather monthly, quarterly and annual statistics, which record the most important information such as the number of messages and their values. When analyzing these data, it is easy to see that the Express Elixir system has 
Table 5. Express Elixir - summary of the number and value of transactions

\begin{tabular}{|c|c|c|c|c|c|c|c|c|c|}
\hline & \multicolumn{8}{|c|}{ Express Elixir } \\
\hline & & \multirow{2}{*}{$\begin{array}{c}\text { Number of } \\
\text { messages } \\
\text { [thous.] }\end{array}$} & \multirow{2}{*}{$\begin{array}{c}\text { Value } \\
{[\text { PLN }} \\
\text { mn] }\end{array}$} & \multicolumn{2}{|c|}{ Annual difference } & \multicolumn{2}{|c|}{$\begin{array}{c}\text { Dynamics (mon- } \\
\text { thly) }\end{array}$} & \multicolumn{2}{|c|}{ Dynamics (annual) } \\
\hline & & & & $\begin{array}{c}\text { Number of } \\
\text { messages } \\
\text { [thous.] }\end{array}$ & $\begin{array}{c}\text { Value } \\
\text { [PLN } \\
\text { mn] }\end{array}$ & $\begin{array}{c}\text { Number } \\
\text { of messa- } \\
\text { ges [\%] }\end{array}$ & $\begin{array}{l}\text { Value } \\
{[\%]}\end{array}$ & $\begin{array}{c}\text { Number of } \\
\text { messages } \\
{[\%]}\end{array}$ & $\begin{array}{l}\text { Value } \\
{[\%]}\end{array}$ \\
\hline \multirow{12}{*}{$\stackrel{\vec{d}}{\vec{d}}$} & January & 39.4 & 248 & 17.3 & 179.0 & 3.68 & 6.44 & 78.28 & 259.42 \\
\hline & $\begin{array}{l}\text { Febru- } \\
\text { ary }\end{array}$ & 38.4 & 217 & 20.2 & 122.0 & -2.54 & -12.50 & 110.99 & 128.42 \\
\hline & March & 52.4 & 271 & 31.6 & 163.0 & 36.46 & 24.88 & 151.92 & 150.93 \\
\hline & April & 63.3 & 294 & 43.8 & 194.0 & 20.80 & 8.49 & 224.62 & 194.00 \\
\hline & May & 69.5 & 299 & 47.1 & 179.0 & 9.79 & 1.70 & 210.27 & 149.17 \\
\hline & June & 80.0 & 346 & 53.8 & 193.0 & 15.11 & 15.72 & 205.34 & 126.14 \\
\hline & July & 88.4 & 380 & 59.6 & 213.0 & 10.50 & 9.83 & 206.94 & 127.54 \\
\hline & August & 82.9 & 334 & 53.7 & 181.0 & -6.22 & -12.11 & 183.90 & 118.30 \\
\hline & $\begin{array}{l}\text { Sep- } \\
\text { tember }\end{array}$ & 94.3 & 411 & 60.9 & 212.0 & 13.75 & 23.05 & 182.34 & 106.53 \\
\hline & $\begin{array}{l}\text { Octo- } \\
\text { ber }\end{array}$ & 104.2 & 480 & 67.8 & 270.0 & 10.50 & 16.79 & 186.26 & 128.57 \\
\hline & \begin{tabular}{|l|}
$\begin{array}{l}\text { Novem- } \\
\text { ber }\end{array}$ \\
\end{tabular} & 107.3 & 479 & 72.3 & 286.0 & 2.98 & -0.21 & 206.57 & 148.19 \\
\hline & $\begin{array}{l}\text { Decem- } \\
\text { ber }\end{array}$ & 120.2 & 524 & 82.2 & 291.0 & 12.02 & 9.39 & 216.32 & 124.89 \\
\hline \multirow{12}{*}{$\stackrel{n}{\stackrel{n}{8}}$} & January & 107.0 & 422.5 & 67.6 & 174.5 & -10.98 & -19.37 & 171.57 & 70.36 \\
\hline & $\begin{array}{l}\text { Febru- } \\
\text { ary }\end{array}$ & 105.4 & 464 & 67.0 & 247.0 & -1.50 & 9.82 & 174.48 & 113.82 \\
\hline & March & 119.0 & 567 & 66,6 & 296,0 & 12,90 & 22,20 & 127,10 & 109,23 \\
\hline & April & 120.0 & 511 & 56.7 & 217.0 & 0.84 & -9.88 & 89.57 & 73.81 \\
\hline & May & 116.0 & 521 & 46.5 & 222.0 & -3.33 & 1.96 & 66.91 & 74.25 \\
\hline & June & 80.0 & 345.6 & 0.0 & -0.4 & -31.03 & -33.67 & 0.00 & -0.12 \\
\hline & July & 125.7 & 561 & 37.3 & 181.0 & 57.13 & 62.33 & 42.19 & 47.63 \\
\hline & August & 121.5 & 538 & 38.6 & 204.0 & -3.34 & -4.10 & 46.56 & 61.08 \\
\hline & \begin{tabular}{|l|} 
Sep- \\
tember
\end{tabular} & 135.0 & 617 & 40.7 & 206.0 & 11.11 & 14.68 & 43.16 & 50.12 \\
\hline & \begin{tabular}{|l|} 
Octo- \\
ber
\end{tabular} & 139.6 & 648.8 & 35.4 & 168.8 & 3.41 & 5.15 & 33.97 & 35.17 \\
\hline & $\begin{array}{l}\text { Novem- } \\
\text { ber }\end{array}$ & 136.5 & 607.2 & 29.2 & 128.2 & -2.22 & -6.41 & 27.21 & 26.76 \\
\hline & \begin{tabular}{|l|}
$\begin{array}{l}\text { Decem- } \\
\text { ber }\end{array}$ \\
\end{tabular} & 148.2 & 696 & 28.0 & 172.0 & 8.57 & 14.62 & 23.29 & 32.82 \\
\hline \multirow{3}{*}{ 을 } & January & 135.5 & 587.3 & 28.5 & 164.8 & -8.57 & -15.62 & 26.64 & 39.01 \\
\hline & \begin{tabular}{|l|}
$\begin{array}{l}\text { Febru- } \\
\text { ary }\end{array}$ \\
\end{tabular} & 141.8 & 612.6 & 36.4 & 148.6 & 4.65 & 4.31 & 34.54 & 32.03 \\
\hline & March & 182,2 & 761,8 & 63,2 & 194,8 & 28,49 & 24,36 & 53,11 & 34,36 \\
\hline
\end{tabular}

Source: own work based on materials provided by the Automated Clearing House KIR. 
Table 6. BlueCash - summary of the number and value of transactions

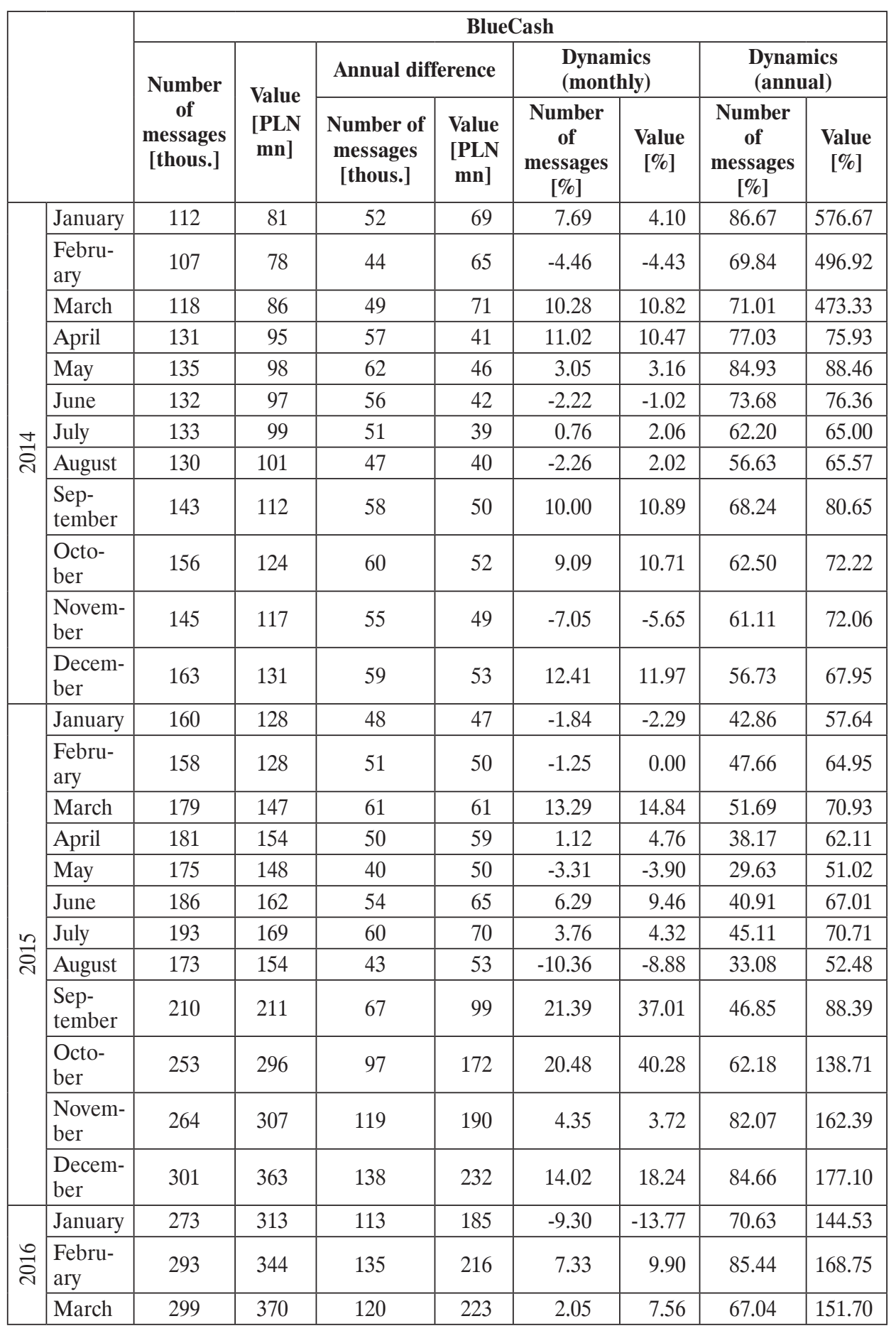

Source: own work based on materials provided by the Automated Clearing House KIR and Blue Media $S . A$. 
higher values of payments (Table 5), and the BlueCash system has a higher number of messages (Table 6). Each message can be understood as a one-off payment. This property is related to the nature of both systems. The BlueCash system is normally used for cash transactions of a limited value such as payment of monthly bills or current shopping, which generates a large number of messages. On the other hand, the Express Elixir system has a lower number of messages (transactions) but has a higher average value. Thanks to Express
Elixir, Poland became the second country with a professional payment system (the first one is the United Kingdom with the Faster Payments Service system), but the BlueCash system makes Poland the only country that has two immediate payment systems (Table 7).

The Polish immediate payment systems stand out among their European counterparts and even outpace them in terms of applied innovative solutions. Although these systems are still relatively new, they are spreading rapidly.

Table 7. Comparison of immediate payment systems in Poland and EU

\begin{tabular}{|c|c|c|c|c|c|}
\hline & United Kingdom & Poland & Poland & Sweden & Denmark \\
\hline System & $\begin{array}{l}\text { Faster Payments } \\
\text { Service }\end{array}$ & $\begin{array}{l}\text { Express } \\
\text { Elixir }\end{array}$ & BlueCash & $\begin{array}{l}\text { Betalningar } \\
\text { i Realtid } \\
\text { (BiR) }\end{array}$ & Straksclearnig \\
\hline $\begin{array}{l}\text { System } \\
\text { operator }\end{array}$ & Vocalink Ltd & KIR S.A. & $\begin{array}{l}\text { Blue Media } \\
\text { S.A. }\end{array}$ & Bankgirot & NETS \\
\hline $\begin{array}{l}\text { Entity in charge } \\
\text { of the system }\end{array}$ & $\begin{array}{l}\text { Faster Payments } \\
\text { Scheme Ltd }\end{array}$ & KIR S.A. & $\begin{array}{l}\text { Blue Media } \\
\text { S.A. }\end{array}$ & Bankgirot & $\begin{array}{c}\text { Danish } \\
\text { Bankers } \\
\text { Association }\end{array}$ \\
\hline Launch date & May 2008 & June 2012 & $\begin{array}{c}\text { November } \\
2012\end{array}$ & $\begin{array}{c}\text { November } \\
2012\end{array}$ & $\begin{array}{c}\text { November } \\
2014\end{array}$ \\
\hline $\begin{array}{l}\text { System } \\
\text { availability }\end{array}$ & $24 / 7 / 365$ & $24 / 7 / 365$ & $24 / 7 / 365$ & $24 / 7 / 365$ & $24 / 7 / 365$ \\
\hline $\begin{array}{l}\text { Speed of } \\
\text { payment } \\
\text { execution }\end{array}$ & $\begin{array}{l}\text { A few minutes } \\
\text { for direct } \\
\text { participants, } \\
2 \text { hours for } \\
\text { intermediate } \\
\text { participants }\end{array}$ & $\begin{array}{l}\text { A dozen } \\
\text { of seconds }\end{array}$ & $\begin{array}{c}10-15 \\
\text { seconds } \\
\text { (in practice } \\
\text { up to } \\
15 \text { minutes) }\end{array}$ & 15 seconds & A few seconds \\
\hline Amount limits & GBP 100000 & PLN 100000 & PLN 20000 & - & DKK 500000 \\
\hline $\begin{array}{l}\text { Method of } \\
\text { payment } \\
\text { initiation }\end{array}$ & $\begin{array}{c}\text { Smartphone } \\
\text { (mobile } \\
\text { payments), } \\
\text { Secure-IP } \\
\text { solution for } \\
\text { business clients }\end{array}$ & $\begin{array}{l}\text { Internet } \\
\text { banking, } \\
\text { physically } \\
\text { at the } \\
\text { branch and } \\
\text { telephone }\end{array}$ & $\begin{array}{l}\text { Internet } \\
\text { banking, } \\
\text { physically } \\
\text { at the } \\
\text { branch and } \\
\text { telephone }\end{array}$ & $\begin{array}{c}\text { The } \\
\text { application } \\
\text { for } \\
\text { Smartphone } \\
\text { and mobile } \\
\text { devices }\end{array}$ & $\begin{array}{l}\text { Internet } \\
\text { banking }\end{array}$ \\
\hline $\begin{array}{l}\text { Type of } \\
\text { participation }\end{array}$ & $\begin{array}{l}\text { Direct, indirect } \\
\text { (corporations) }\end{array}$ & Direct & $\begin{array}{c}\text { Direct, } \\
\text { cooperating } \\
\text { banks }\end{array}$ & $\begin{array}{l}\text { Direct, } \\
\text { indirect }\end{array}$ & $\begin{array}{l}\text { Direct, } \\
\text { indirect }\end{array}$ \\
\hline $\begin{array}{l}\text { The ISO used } \\
\text { for the payment } \\
\text { message }\end{array}$ & ISO8583 & ISO20022 & ISO20022 & ISO20022 & ISO20022 \\
\hline
\end{tabular}

Source: own work based on materials provided by the National Bank of Poland (https://www.nbp.pl/ systemplatniczy/platnosci-natychmiastowe/systemy-platnosci-natychmiastowych.pdf). 


\section{Evaluation of Effectiveness of Immediate Payment System Management on the Polish Financial Market}

Careful payment system management is especially important at times of constant technological changes. It is crucial to track the needs of financial services market participants as well as to set new directions or adopt existing foreign market trends on the Polish market. The goal of this study is to assess the effectiveness of the payment management systems operating on the Polish financial services market since they were launched in March 2016, based on four key indicators: the number of users, the number of settled transactions, the value of transactions and, above all, the time needed to settle a transaction. This analysis has to answer the following question: Are the immediate payment systems for the Polish financial services market well managed? The answer to this question has been prepared on the basis of own research.

To find the starting point for future research on immediate payment system management, one should form a hypothesis. In this case, it will be: Immediate payment systems for the financial services market in Poland are well managed.

\subsection{Analysis of the Express Elixir System}

The number of messages and their value for Express Elixir increase significantly each year (Table 5). From the moment the system was launched (June 2012) to the end of 2015, the number of messages increased more than 65 -fold, and their value went up almost 83 -fold. Year by year, the usage of the system increases, and in the first quarter of 2016 it exceeded the values it had reached during the entire 2013. This result demonstrates the meticulous implementation of the plan, which involves acquiring as many customers of immediate systems as possible.

In order to better illustrate the trend of these changes, a chart with a trend line based on the message value was created (Figure 2). The chart shows a trend line based on monthly data. It is estimated that in 2016 the number of messages and their values will reach a record level once again.

The trend line based on the message value shows a steady increase. To check the fit to the data line, the determination coefficient $R^{2}$ was calculated:

$$
R^{2}=\frac{\sum_{i=1}^{n}\left(\widehat{y_{i}}-\bar{y}\right)^{2}}{\sum_{i=1}^{n}\left(y_{i}-\bar{y}\right)^{2}}=0.961
$$

where:

$\widehat{y}$-theoretical value of $Y$ variable in $i$ period,

$\bar{y}$-average value of $Y$ for $n$ length time series,

$y_{i}$ - value of $Y$ variable in $i$ period.

The results of $R^{2}$ indicate a very good fit to the value of message data. In the next step of immediate payment analysis, the second half of 2014 and the first half of 2015 were compared (Table 8).

Table 8. Express Elixir - comparison of the first half of 2015 and the second half of 2014

\begin{tabular}{|l|r|r|}
\hline & \multicolumn{1}{|c|}{$\begin{array}{c}\text { First half } \\
\text { of 2015 }\end{array}$} & \multicolumn{1}{|c|}{$\begin{array}{c}\text { Second } \\
\text { half of } \\
\mathbf{2 0 1 4}\end{array}$} \\
\hline $\begin{array}{l}\text { Number of working } \\
\text { days }\end{array}$ & 181 & 184 \\
\hline \multicolumn{2}{|c|}{ Number of messages (thous.) } \\
\hline Total & 689409 & 597283 \\
\hline Average per month & 114902 & 99547 \\
\hline Daily average & 3809 & 3246 \\
\hline $\begin{array}{l}\text { Average amount of } \\
\text { daily orders (PLN) }\end{array}$ & 4412.1 & 4320.7 \\
\hline \multicolumn{2}{|c|}{ Value of messages (PLN) } \\
\hline Total & $3.042 \mathrm{bn}$ & $2.581 \mathrm{bn}$ \\
\hline Average per month & $507 \mathrm{mn}$ & $430.1 \mathrm{mn}$ \\
\hline Daily average & $16.805 \mathrm{mn}$ & $14.025 \mathrm{mn}$ \\
\hline
\end{tabular}

Percentage share of the number of messages in a given time period

\begin{tabular}{|l|r|r|}
\hline 0:01 - 8:00 & $4 \%$ & $3.8 \%$ \\
\hline 8:01 - 16:00 & $65.4 \%$ & $66.3 \%$ \\
\hline 16:01 - 24:00 & $30.6 \%$ & $29.9 \%$ \\
\hline
\end{tabular}

Percentage share of the number of messages on a day of the week

\begin{tabular}{|l|r|r|}
\hline Monday & $20 \%$ & $20.4 \%$ \\
\hline Tuesday & $18 \%$ & $18.3 \%$ \\
\hline Wednesday & $17 \%$ & $18 \%$ \\
\hline Thursday & $16.5 \%$ & $16.9 \%$ \\
\hline Friday & $19.8 \%$ & $18.5 \%$ \\
\hline Saturday & $4.9 \%$ & $4.4 \%$ \\
\hline Sunday & $3.8 \%$ & $3.5 \%$ \\
\hline
\end{tabular}

Source: own work based on materials provided by the Automated Clearing House KIR. 


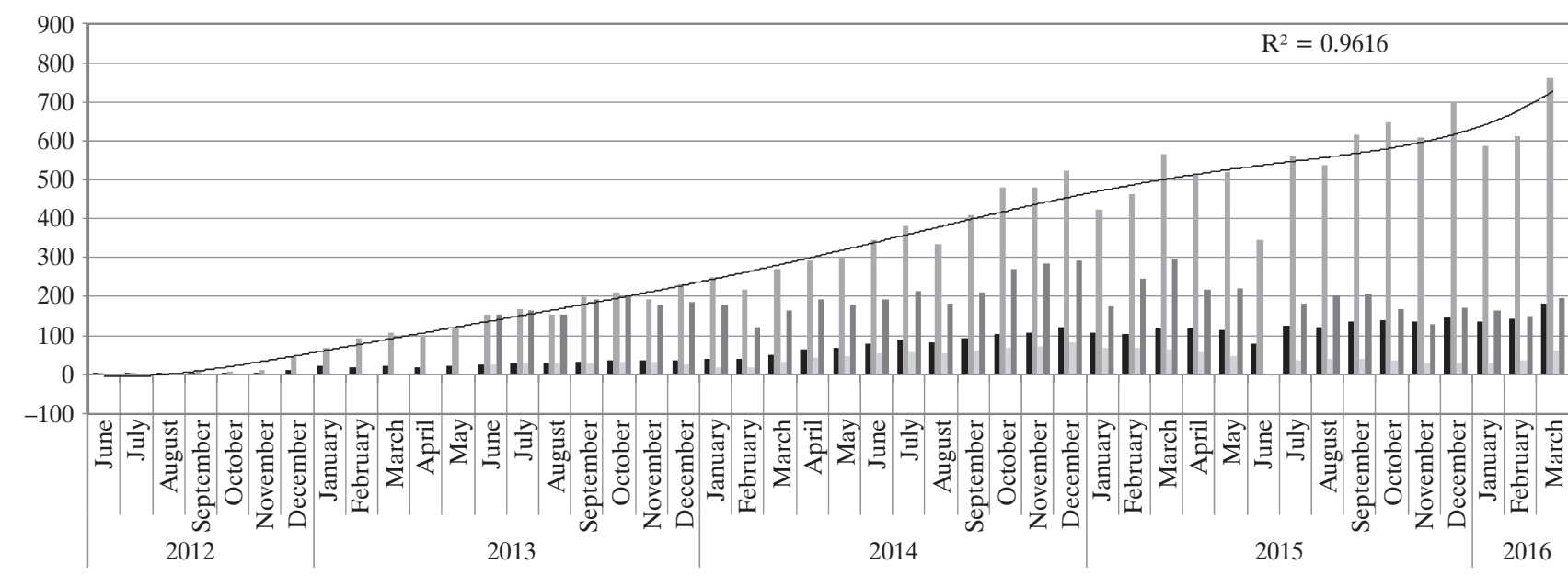

-Number of messages [thous.] $₫$ Value of messages [PLN mn] $\backsim$ Annual differene between number $\backsim$ Annual differene between value of messages [thous.] of messages [PLN mn]

Source: own work based on materials provided by the Automated Clearing House KIR. 
The immediate payment system Express Elixir had the greatest load on Mondays and Fridays from 8:00 to 16:00. This does not change the fact that its effectiveness must be ensured also at other times, including holidays, days free from work and weekends.

The growing number of processed messages also translates into an increase in the average daily amount of messages and their value. Such a strong growth observed in a relatively short time period proves efficient implementation of the development strategy and successful promotion among potential customers. Undoubtedly, the most important aspect for future system development is to encourage more banks to join the systems and use them more frequently.

\subsection{Analysis of the BlueCash System}

A similar situation can be observed also in the case of the other immediate payment system, BlueCash. This system was established in November 2012, but it was officially launched in January 2013. The difference between these dates results from the 2-month system testing period. As can be seen on the chart below (Figure 3), the number of messages and their value goes up significantly year after year. The growth is attributable to system-related management activities as well as its increasing popularity among users. The number of users of the BlueCash system is growing very fast; in the fourth quarter of 2015 alone (compared to the second quarter of 2013), the number of users went up 19-fold, from 4 to 76.

The trend line was also constructed based on the value of messages. The value of the determination coefficient $R^{2}$ is:

$$
R^{2}=\frac{\sum_{i=1}^{n}\left(\widehat{y_{i}}-\bar{y}\right)^{2}}{\sum_{i=1}^{n}\left(y_{i}-\bar{y}\right)^{2}}=0.970
$$

Similarly as in the Express Elixir case, also a statistical comparison for the second half of 2014 and the first half of 2015 was created for BlueCash (Table 9).

Statistics calculated for the BlueCash immediate payment system show a continuing increase in the average number and average value of daily messages. Similarly as in the case of Express Elixir, payments are mostly made from Monday till Friday between 8:00 and 16:00.
Table 9. BlueCash - comparison of the first half of 2015 and the second half of 2014

\begin{tabular}{|l|r|r|}
\hline & $\begin{array}{r}\text { First half } \\
\text { of } \mathbf{2 0 1 5}\end{array}$ & $\begin{array}{c}\text { Second } \\
\text { half of } \\
\mathbf{2 0 1 4}\end{array}$ \\
\hline $\begin{array}{l}\text { Number of working } \\
\text { days }\end{array}$ & 181 & 184 \\
\hline \multicolumn{2}{|c|}{ Number of messages (thous.) } \\
\hline Total & 1039418 & 871474 \\
\hline Average per month & 173236 & 145246 \\
\hline Daily average & 5743 & 4736 \\
\hline $\begin{array}{l}\text { Average amount of } \\
\text { daily orders (PLN) }\end{array}$ & 835 & 786 \\
\hline \multicolumn{3}{|c|}{ Value of messages (PLN) } \\
\hline Total & $867.7 \mathrm{mn}$ & $685.1 \mathrm{mn}$ \\
\hline Average per month & $144.6 \mathrm{mn}$ & $114.2 \mathrm{mn}$ \\
\hline Daily average & $4.8 \mathrm{mn}$ & $3.7 \mathrm{mn}$ \\
\hline
\end{tabular}

Percentage share of the number of messages in a given time period

\begin{tabular}{|l|r|r|}
\hline $0: 01-8: 00$ & $3.8 \%$ & $3.7 \%$ \\
\hline $8: 01-16: 00$ & $60.6 \%$ & $60.9 \%$ \\
\hline 16:01-24:00 & $35.6 \%$ & $35.4 \%$ \\
\hline
\end{tabular}

Percentage share of the number of messages on a day of the week

\begin{tabular}{|l|r|r|}
\hline Monday & $19.6 \%$ & $19.9 \%$ \\
\hline Tuesday & $17.9 \%$ & $18.1 \%$ \\
\hline Wednesday & $16.9 \%$ & $17.6 \%$ \\
\hline Thursday & $16.4 \%$ & $16.5 \%$ \\
\hline Friday & $19.2 \%$ & $18.0 \%$ \\
\hline Saturday & $5.8 \%$ & $5.5 \%$ \\
\hline Sunday & $4.2 \%$ & $4.4 \%$ \\
\hline
\end{tabular}

Source: own work based on materials provided by the Blue Media S.A.

\subsection{Comparison of Express Elixir and BlueCash Systems}

The immediate payment systems on the Polish financial services market are characterized by significant differences (even though they have the same purpose - effecting payments). The first difference between these two systems is the number of messages processed by the system (Figure 4). A growth in this number usually means an increase in the number of system users. Both systems strive to achieve the best results in terms of the number and 


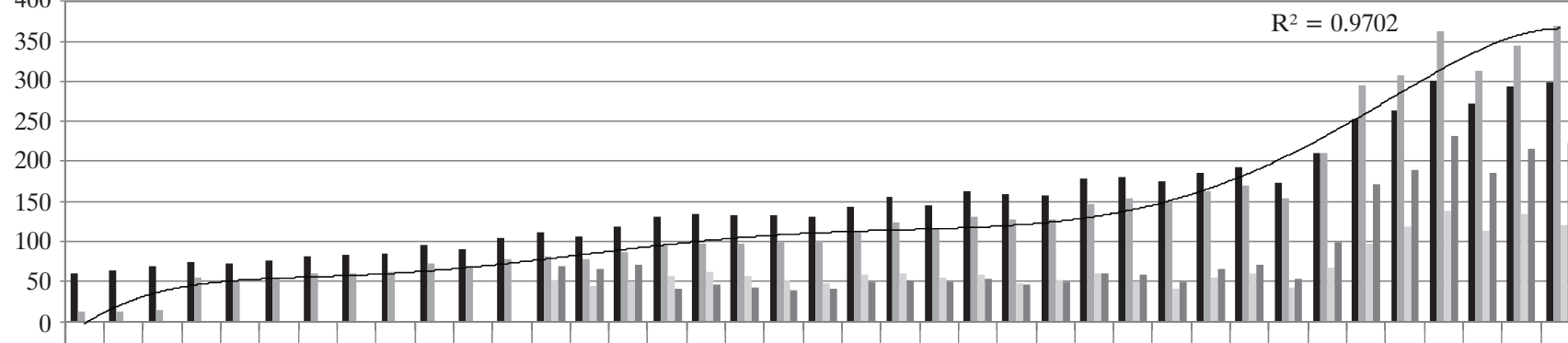

(2) $-50$

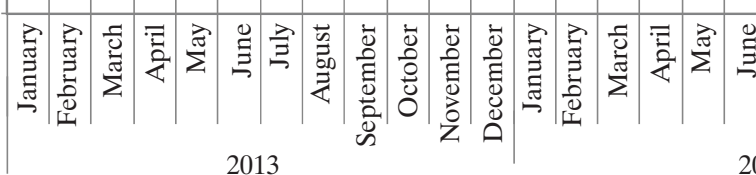

2013

2014
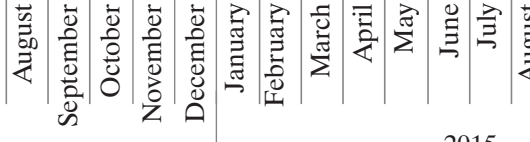

- BlueCash Number of messages [thous.]

- BlueCash Value of messages [PLN mn]

2015

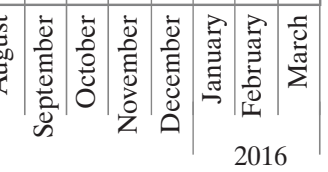

BlueCash Annual differene between number of messages [thous.]

- BlueCash Annual differene between value of messages [PLN mn]

Source: own work based on materials provided by the Automated Clearing House KIR and Blue Media S.A. 


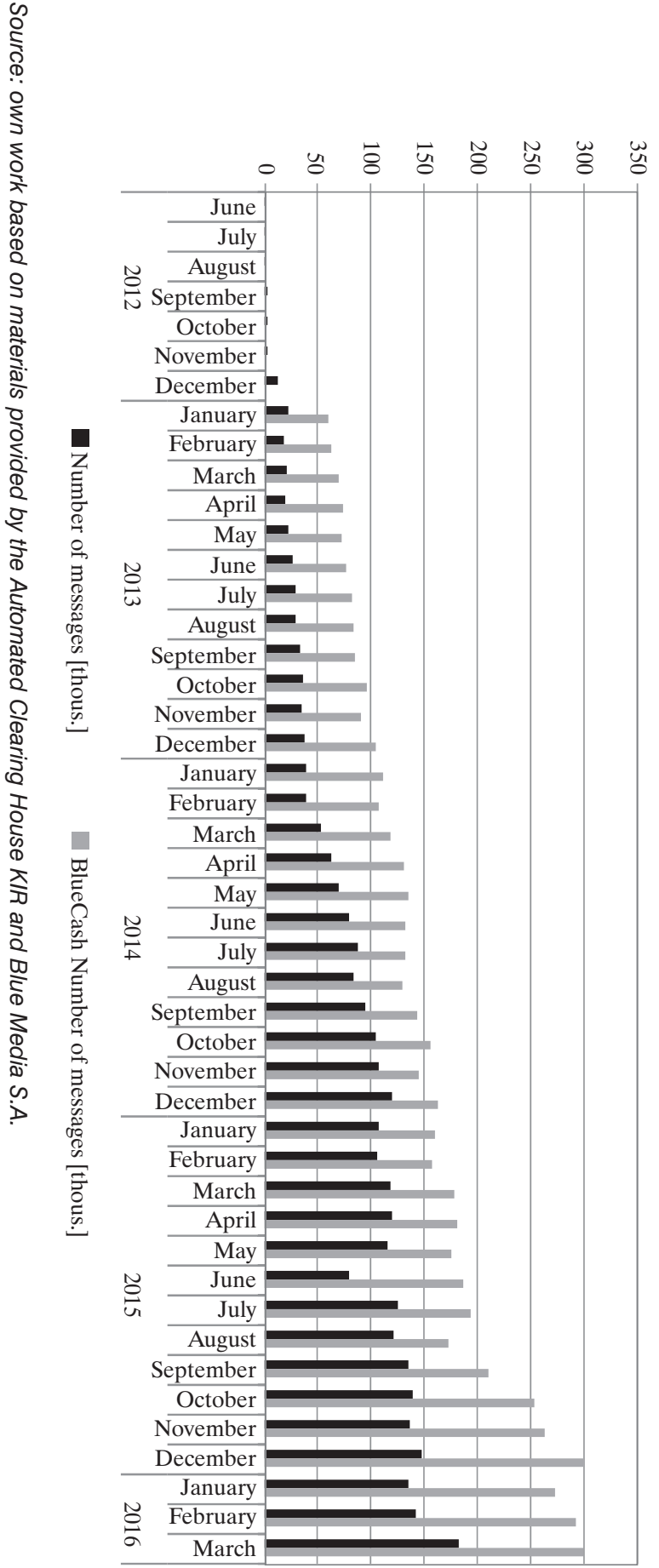


value of messages, and effective system management reduces complaints related to settlements to a minimum level. In case of problems or doubts, Express Elixir and BlueCash have a Customer Service with response time for data application normally below 24 hours from the moment of inquiry.

The BlueCash system has more messages, sometimes even twice more than its competitor, Express Elixir. As mentioned above, this is due to the number of users and the types of payments (small payments, for example fees). Because of charges set by banks, Express Elixir is usually selected by corporate clients. Individual (retail) users usually choose the Elixir system which is free but slower in operation. The situation with payments looks different in the case of the BlueCash system which charges a commission for money transfers and does not offer any free variant. That is why the BlueCash system is mainly used by customers making monthly payments (such as electricity, gas, media charges), which allows obtaining a higher number of messages than in the case of Express Elixir.

The total value of messages follows a different pattern, with a reversed trend where Express Elixir generates a higher total value. In some cases, the total value of messages is twice or three times higher than in the competitive BlueCash system.

After less than four years after the launch of the immediate payment systems on the Polish financial services market, their role in the payment system is still relatively insignificant. It is hard to view immediate payments as an alternative to traditional payment methods (such as the Elixir system), and it is better to treat them as a rather more modern and faster solution. However, the pace of their development as well as the number and value of messages confirm the existence of market demand for such services and the need for effective system management. For the payment systems to develop even faster and reach a larger number of participants, it is necessary to expand the range, increase availability, support their development and promote this type of transactions among retail customer. It is also worth noticing that the functioning of these two types of payment systems on the Polish financial services market brings beneficial effects.
Since both systems have to compete for customers, they must be managed in a very meticulous manner, with a focus on actions. As a result, system users get better, faster and cheaper products. So what is the advantage of one system over the other, which also helps to develop immediate payment systems? It is the direct nature of transactions in the Express Elixir system and, more specifically, the implementation of instant transfers directly between banks. The payment messages generated in these transactions are processed by KIR SA, the institution responsible for the settlement of almost all domestic transfers. In addition, the construction of the system, which is based on a direct link with the right current account in the National Bank of Poland, is a guarantee of transaction security. In the Express Elixir system, funds are transferred between banks, and they do not leave the banking sector. In contrast, in the BlueCash system, funds transferred between banks are at the disposal of a commercial institution. Moreover, the whole transfer operation is carried out by way of internal transfers through a number of banks that are system participants.

\subsection{Proposals for the Development of Support for Immediate Payment Systems}

Four years since the launch of the immediate payment systems, their role on the Polish financial services market is still relatively insignificant, and their share in the volume of retail payments is minimal. It is hard to say that immediate payments are an alternative to traditional payment methods, but they give more opportunities (such as making transfers during night hours or holidays). However, the speed of their development shows that the Polish financial market needs this kind of services. For even faster growth, the immediate payment system needs to increase the number of users, expand system coverage, availability, support the development of and promote this type of money transfers among retail customers.

\section{Conclusion}

The studies on the immediate payment systems confirm the research hypothesis. The existence of two different types of immediate payment systems on the 


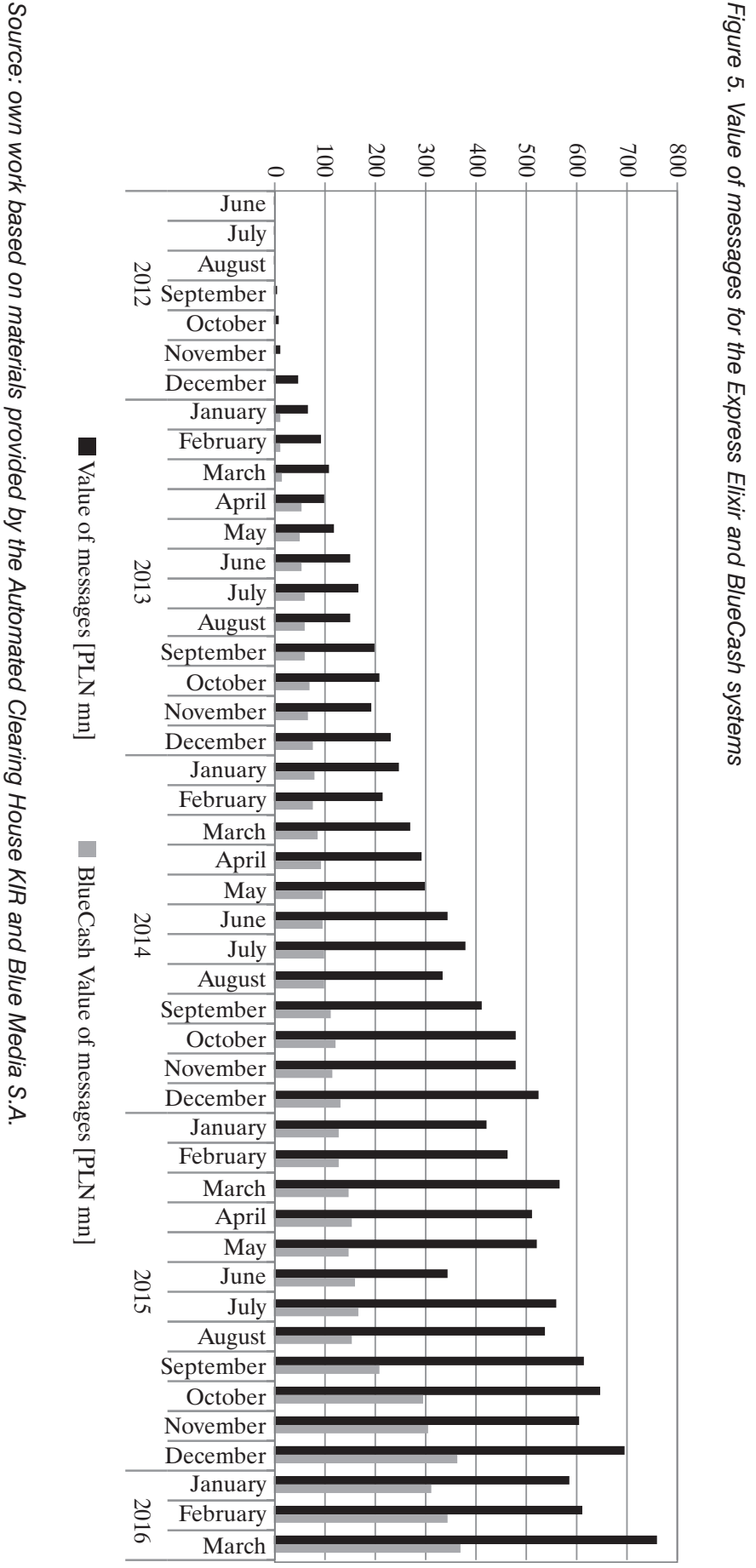


Polish financial market brings positive effects. Both systems have to compete for customers, must be managed in a very meticulous way (focused on actions rather than on profits), which means that the system users get better, faster and cheaper products. So what is the advantage of one system over the other? It is the direct nature of the immediate payments in the Express Elixir system, which is based on direct transactions between banks Generated messages are processed by KIR S.A. (the organization responsible for the settlement of almost all domestic transfers), and the system structure is based on a direct link with the correct current account in the National Bank of Poland (which can be treated as a guarantee of security of undertaken transactions). The funds in the Express Elixir system are transferred between banks (without leaving this sector); in contrast to the BlueCash system. In the case of the second system, during the transfer between banks the funds are at the disposal of the commercial organizations, and the whole operation is carried out through a number of banks that are participants in the system (by internal transfer). During this operation, many unforeseen events can slow down the fund transfer process.

\section{References}

Artto, K.A. and Dietrich, P.H. (2007). Strategic business management through multiple projects. In: P.W.G. Morris and J.K. Pinto (eds.), The Wiley guide to project program \& portfolio management (pp. 1-33). Hoboken, NJ: John Wiley \& Sons.

Gowrisankaran, G. and Stavins, J. (2004). Network externalities and technology adoption: Lessons from electronic payments. RAND Journal of Economics, 35(2), 260-276.

Grundy, T. (2000). Strategic project management and strategic behavior. International Journal of Project Management, 18(2), 93-104.

Kauffman, R.J. and Wang, Y.M. (2002). The network externalities hypothesis and competitive network growth. Journal of Organizational Computing and Electronic Commerce, 12(1), 59-83.

Korzeń, K. (2006), Bankowość elektroniczna jako kanat dystrybucji ustug bankowych. Poznań: integraf - Anna Dygas.

Krawiec, F. (2011). Zarzadzanie strategia firmy. Warszawa: Difin.
Krzywda, J. and Dolniak, R. (2014). Najnowsze trendy w dystrybucji w branży fonograficznej w Polsce. In: M. Kadłubek, Komplementarność koncepcji zarzadzania i logistyki - Strategia i dystrybucja w logistyce produkcji i ustug. Częstochowa: Politechnika Częstochowska, Wydział Zarządzania.

Samuelson, P.A. and Nordhaus, W.D. (2012). Ekonomia. Poznań: REBI.

Skrzypek, E. (2012). Efektywność ekonomiczna jako ważny czynnik sukcesu organizacji. In: T. Dudycz, G. Osbert-Pociecha and C. Brycz (eds.), Efektywność - konceptualizacja i uwarunkowania. Prace Naukowe Uniwersytetu Ekonomicznego we Wrocławiu no. 262. Wrocław: Wydawnictwo Uniwersytetu Ekonomicznego we Wrocławiu.

Van Hove, L. (1999). Electronic money and the network externalities theory: Lessons for real life. Netnomics, 1(2), 137-171.

Wilczyński, R. (2014). Pomiar efektywności a cele przedsiębiorstw. Zeszyty Naukowe Uniwersytetu Szczecińskiego, 803, Finanse, Rynki Finansowe, Ubezpieczenia, 66. Szczecin: Wydawnictwo Naukowe Uniwersytetu Szczecińskiego. 